\title{
Omówienia
}

DOI: $10.14746 /$ por.2018.2.24

\section{IMAGOLOGY - ETHNIC STEREOTYPES OF THE V4 COUNTRIES}

\author{
Monika Adamická ${ }^{1}$
}

Zelenka Miloš, Tkáč-Žabáková Lenka, eds. Imagológia ako výskum obrazov kultúry. Nitra: FSŠ UKF v Nitre, 2018. 162 S.

The collective volume Imagology as Research of Cultural Image was developed as part of the VEGA 1/0629/17 Ethnic Stereotype Project in the V4 Literature. The project has been solved by the members of the Central European Interlibrary Relations Team from the Institute of Central European Languages and Cultures of the Faculty of Central European Studies at the Constantine the Philosopher University in Nitra. Imagology as a specific discipline of comparing literary science has an interdisciplinary overhang to semiotics, linguistics, political and historical geography, sociology, anthropology, and others. The publication is a set of the author's texts that bring the theoretical, literary-historical and cultural reflections from the field of imagology, to display ethnic stereotypes in Central European literature and art. In the Central European cultural area there are created specific constructions, images of identity and otherness because of the diversity of ethnicity. The images of identity and otherness express in mutual communication the desire for symbolic unity, but also a hidden discourse of power.

In the initial study, prof. Milos Zelenka suggested the historical development of imagology as a comparative discipline whose main aim is to analyze "the foreign" in literary texts. His contribution gives a basic thesis of imagology in a comprehensive form. The stereoty pical images that nations and nationalities create about themselves and others are, according to Zelenka, a consequence of the need to emphasize proximity and understanding, on the other hand, its own value inheritance and superiority. The definition of distinction or the consciousness of the own distinction towards others also affects the alienation of nations. Zelenka deals with the evolu-

1 E-mail: monika.adamicka@ukf.sk 
tion of imagology since its inception at the end of the 19th century, when the departments of comparatist were formed at French universities. The origins of imagology are related to the names of Madame de Staël, Walter Lippmann and its founder Hugo Dysernick. The author also focuses on areas of contemporary exploration of imagology where the subject is extended as a result of the convergence of humanities and natural sciences to explore images and animals in culture. In conclusion, the main meaning of this comparative discipline is the overcoming of the nationalist notions of the superiority of some nations. "If comparative imagology was developed in different directions in the period of its theoretical existence, its main importance lies in overcoming the nationalist ideas in the social sciences of the value or aesthetic superiority of some nations" (Zelenka, Tkáč-Žabáková 13).

The Stereotypes of Hungarians in the Slovak literature concerned the contributions of Tibor Žilka and Gabriella Petres Csizmadia. Tibor Žilka in his study Ethnicity as a means of stereotypization of (literary) characters, deals with the image of Hungarian characters in Slovak literature and vice versa, Slovak characters in the Hungarian literature in contrast to "own - foreign". The author deals with the topographical symbols (the symbol of the lowland in the Hungarian literature and the symbol of the mountains in the Slovak literature). On the other hand, he analyzed the onomastic symbols. He realized the research of these symbols on important works of the national literature of Slovaks and Hungarians. He characterizes five types of Hungarian characters that can be found in Slovak novels, especially those who represent power, superiority and characters connected with the urban environment. It results from the Hungarians' superiority over the Slovaks during their common history. " ...however, these two views can be differentiated since the social status was not the same - until the formation of Czechoslovakia in 1918, the Hungarians were rather uppermost, socially standing higher, which eventually has its reach also for the selection of the characters and the environment where they exist." (Zelenka, Tkáč-Žabáková 19). Under the influence of this thesis, the Slovak was also promoted in the Hungarian literature as a simple, rural, subjugated, but unsophisticated, detached from the society and under the influence of a minority membership. The contribution Experience of being different in Katarina Durica's novel Milovat' po slovensky written by Gabriella Petres Czimadia analyses the display of Hungarian identity in Slovakia in the novel by Katarina Durica. The isolation of Hungarians living in Slovakia from Hungarians living in Hungary leads to mutual aversion. The novel is a reflection of the role played by the space and language in the creation of identity, as well as how the experience of the foreign leads to the deterioration of identity.

The contributions of Anna Zelenková and Ivan Halász deal with the topic of the Slovak as a rustic person. Anna Zelenková in the Contribution On the Imagological Reflection of The Tinker Topos in the Librettos of J. K. Chmelenský and K. Želenský ("Image of the Neighbour" in the 19th Century Czech-Slovak Cultural Relations) discusses the stereotype of tinker, which was the most widespread image of the Slovak in the 
Czech environment in the 19th century. The image of the tinker is analysed on the example of the opera librettos of J. K. Chmelenský Dráteník (1826) and K. Želenský $U$ božích muk (1898). The Slovak tinker in the Czech environment represented the misery, but also the simple person of a pure character and with positive qualities, and at the same time a person with a national feeling. In the contribution The "Popular" and "Rural" Character of Slovak Literature: Stereotype or Reality? the author Ivan Halász tries to relativize the stereotype about the rural and folk character of Slovak literature from the second half of the 19th and 20th centuries. He relies on the fact that most of the works of this period were written by authors form priest-middle class social groups. The stereotype about the folk and rural character of the Slovak literature was consolidated especially after the establishment of Czechoslovakia, later supported also in the period of communism. However, according to Halász, this stereotype is associated with a period of romanticism and is not only a matter of Slovak literature, but of European romantic literature as a whole. The folk character of Slovak literature is, in his opinion, the result of the absence of larger towns in the Slovak environment, from which he deduced the term non-urban character of Slovak literature. "In the Slovak environment, the problem was rather the lack of a large or at least larger city centre, as well as the overall peripheral position of Slovak regions." (Zelenka, Tkáč-Žabáková 47).

The image of Slovak in the Polish environment is dealt with the study of Tomás Móri titled Stereotype of a Slovak in Poland at the end of the 19th century and today. The study is the result of research that focused on the view of current Poles on stereotype of Slovak. The research results were compared with the 19th century texts dealing with this issue.

The contribution of Peter Káša Who are my Rusyns (Pictures and stereotypes in works of Štefan Suchý) is about the stereotypes about Rusyns. He analyses the work of Štefan Suchý, whose works can be used to find certain images of Rusyns and the perception of Rusyns within V4 countries. Štefan Suchý is a Rusyn author who lives in Slovakia. As the key poem in his work, Káša considers the poem Chcem byt' Slovákom! (2006) in which the author contrasts the Rusyn unspoken, deformed identity with a self-confident Slovak identity. The author's own Rusyn nation receives a negative perception.

Attention is also paid to the stereotype about the Jews in the contributions of Ján Gallik Formation of Stereotypical View on Jews in Slovak Press, Štefan Timko Jewish Minority in Slovak Cinematography and Magdaléna Hrbáček Common Stereotypes of Jews in Central Europe. The image of the Jew is also partly of interest in the study by Hana Guzmická entitled Ethnic Stereotypes of the Characters in a novel by Pavol Rankov Stalo sa proého septembra (alebo inokedy). Except for Jews she also pays attention of how the image of the Czech and the Hungarian is portrayed in the novel of Pavol Rankov.

The study of Ján Gallik is based on two pieces of Slovak literature about Jewry, namely the work of Martin Rázusa Krčmársky král and Gejza Vámoš Odlomená haluz. 
Based on the analysis of these works, he seeks the origin of cultural-social determinants that are involved in creating stereotypes about ethnic groups. According to Gallik, in the novel Krčmársky král "we can reflect a number of images - stereotypes, on the basis of which the literary criticism questioned whether it is not anti-Jewish novel." (Zelenka, Tkáč-Žabáková 74). In the novels of both authors we can see the stereotype about Jews and their connection to the Hungarian element. The Jews are depicted as an ethnic group that has not been associated with Slovak ethnicity, as they identify themselves with Hungarian ethnicity. Similar negative images (stereotypes) about their domination in world politics, the media and publishers are also found in periodicals in the past and present press.

The aim of Štefan Timko's contribution is to analyse the image of Jews in Slovak films from the beginning of Slovak cinematography to the period after 1989. In the pre-war period, we encounter the caricature of the Jew as a pub owner protecting his property. The development of Slovak cinematography with the theme of Jewry was hampered by the anti-Zionist and anti-Semitic attitude of the USSR in the post-war period. Nevertheless, successful films were being created, including Námestie svätej Alžbety and Obchod na Korze. A similar trend is observed after 1989 when "the theme of persecution of Jews in the Slovak films almost disappeared."(Zelenka, Tkáč-Žabáková 93). In the current century, the film of Jiří Chlumský Nedodržaný slub (2009) returns to the theme of Jewry.

The contribution of Magdalena Hrbáček is also interesting from the point of view of the stereotypes of Jews in Central Europe. It deals mainly with the issue of creating a negative stereotype about the Jews, which was also used to spread the ideas of anti-Semitism during the Second World War and which, unfortunately, still persists to some extent. At the beginning of the study, the author defines stereotypes as "generalizations that are being made about certain groups of people. The basis is categorization." (Zelenka, Tkáč-Žabáková 97). Over the course of history, several stereotypes have been created about Jews: merchants, educated Jews or the traveling Jew Ahasver. She also wrote about five stereotypes which are still present in Hungary: different, mean, aggressive, greedy and sly. These stereotypes are also illustrated on the examples of jokes about Jews.

Zoltán Németh in the contribution The Destruction of the Ethnic Stereotypes in the Central European novels with pseudonym analyzed pseudonymous novels in which he tried to prove the presence of ethnic stereotypes in postmodern literature. He connected the usage of a pseudonym with the effect of insecurity while insecurity from the author's name is expanded to the entire text. "We recognize the text through the name of the author, and that is why all the effects of insecurity contained in the name are extended to the whole text, and at the same time it raises the question whether the name is part of the text or not." (Zelenka, Tkáč-Žabáková 54).

Also the contributions of Simona Mikušková and Dominika Hlavinová Tekeliová are interesting in this respect as they are thematically related to the analysis of 
ethnic stereotypes in Slovak folklore and paremiology. Simona Mikušková's contribution entitled Ethnic Stereotypes in Slovak Paremiology focused on the research of Slovak proverbs and sayings in which ethnic stereotypes and prejudices occur. The author' starting point were the works of A. P. Záturecký, Slovenské hádanky and Slovenské príslovia, porekadlá a úslovia. She supplemented her study with research of ethnic stereotypes in today's society to find out how ethnic phraseology is current at the present time. In the Contribution Ethnic Stereotypes in Folk Narratives, Dominika Hlavinová Tekeliová dealt with the ethnic stereotypes in folklore that present various images of "otherness" and "alienity". The author of the study argued that folklore is "an expression of attitudes, values, emotions, or interests of specific social strata of a certain ethnic community." (Zelenka, Tkáč-Žabáková 126). The author also emphasizes the fact that in the Slovak environment the representatives of the elite were collectors and propagators of folklore and stereotypes during the national revival. The national revival and a sense of endangering their own national identity were the initiators of creating a negative image of "others", spreading xenophobic and anti-Semitic ideas.

In the last study written by Lenka Tkáč-Zabáková, Mental image of "the own" and "the foreign" in the street nomenclature of Nitra, the author prefigured the development of street nomenclature in Nitra from the 19th century to the present. While in the 19th century, during the Habsburg monarchy the Hungarian names of streets or streets named after Hungarian personalities dominated, after 1918 " a comprehensive translation of the urban toponymy from Hungarian to Slovak was done" (Zelenka, Tkáč-Žabáková 138). The street nomenclature of Nitra is influenced by tradition. It has a national character and in the past it changed under the influence of social and political changes, the spread of autostereotypes, but also the ideas about foreign realities.

The final pages of the publication include the Slovak translation of Hugo Dysernick's work Comparative Imagology who was one of the founders of the imagological method. Dysernick defined the fundamental mission of imagology by claiming that "comparative imagology seeks, in the first place, to grasp forms of image representation, its origins and actions. Besides that it wants to contribute to the illumination of the role of literary images at the confrontation of individual cultures." (Zelenka, Tkáč-Žabáková 149). Individual images can be examined firstly as "auto-image", secondly as "hetero-image" (creating images of others).

The publication Imagology as Research of Cultural Image contains a number of contributions to the images and stereotypes of nations and nationalities in Central Europe, in the V4 countries. Except for the texts focusing on the theoretical foundations of imagology as a comparative literary science by Zelenka and Dysernick, the publication includes studies that provide information on how individual nations perceive themselves and others on the contrast of "ours" and "theirs". 
MONIKA ADAMICKÁ, IMAGOLOGY - ETHNIC STEREOTYPES OF THE V4 COUNTRIES

\section{REFERENCES}

Zelenka Miloš, Tkáč-Žabáková Lenka, eds. Imagológia ako výskum obrazov kultúry. Nitra: FSŠ UKF v Nitre, 2018. 